\title{
Digestibility of an Arboreal Lichen by Mule Deer
}

\author{
CHARLES T. ROBBINS
}

\begin{abstract}
Arboreal lichens are commonly consumed by wintering cervids in temperate forests, but their nutritional value is poorly understood. The digestibility of an arboreal lichen (Alectoria sarmentosa) fed with alfalin pellets to mule deer (Odocollews hemionus) was estimated. The lichen contained $2 \%$ crude protein, $13.4 \%$ neutral detergent fiber (NDF), and $\mathbf{0 . 9 \%}$ acid detergent fiber (ADF). Apparent digestibillties were very high for lichen dry matter (85.2\%), NDF (91.9\%), and cell solubles (84.2\%). The apparent digestiblitity of protein was very low $(-218.0 \%)$ and reflects the impossiblitity of balancing MFN losses with a forage containing such minimal nitrogen. This lichen can be an important source of energy to wintering cervids.
\end{abstract}

Key Words: digestion, forage quality, nitrogen, fiber, mule deer, lichens

Arboreal lichens are commonly consumed during winter by many ungulates in north temperate forests (Rochelle 1980, Hodgman and Bowyer 1985). Although lichens are assumed to nutritionally valuable, in vitro digestibilities of arboreal lichens frequently are low (Rochelle 1980, Thomas and Kroeger 1981, Hanley and McKendrick 1983). However, lichen digestibilities determined with nylon bag techniques often exceed results from in vitro systems (Person et al. 1980). Lichens contain numerous antimicrobial compounds that may depress in vitro digestibilities (Person et al. 1980, Robbins et al. 1987b). To further complicate in vitro assessments, lichen digestibilities may increase as incubation times are extended to as long as $180 \mathrm{hr}$ (Thomas and Kroeger 1981, Thomas et al. 1984). Because the same species of lichens consumed by free-ranging deer are often rejected by captive deer (Silver and Colovos 1957), in vivo digestibility of arboreal lichens is poorly understood. Consequently, the following digestion trials with Alectoria sarmentosa were undertaken to determine if this arboreal lichen is nutritionally important to wintering deer.

\section{Methods}

Approximately $60 \mathrm{~kg}$ of Alectoria sarmentosa was collected during October 1984 and May 1985 on Vancouver Island, British Columbia, Canada. Lichens were air-dried and all extraneous matter (bark, twigs, or leaves) removed. The lichens were stored in a dry, unheated barn prior to being fed. The digestion trials used 5 adult, female mule deer. Early attempts to feed a pure lichen diet were unsuccessful as the deer became anorectic. Attempts to forcefeed 150 to $200 \mathrm{~g}$ lichens twice daily via a rumen fistula also failed. Consequently, the only useful technique to determine the digestibility in vivo was to feed a mixed diet and estimate the lichen digestibility by difference. Because it was hypothesized that the lichens would be highly digestible with relatively low levels of protein (Rochelle 1980), alfalfa pellets were chosen as the other diet component. The much lower dry matter digestibility and higher level of crude protein in the alfalfa pellets would be sufficiently different from the lichens to permit an estimate of lichen digestibility by difference even at relatively low levels of lichen intake. This approach assumes a constant digestibility of the alfalfa pellets with no interaction between the alfalfa pellets and the lichen.

\footnotetext{
Author is profeseor and chair of Wildlife Biology, Program in Wildlife Biology, Washington State University, Pullman, Wash. 99164-4220. The author thanks Dr. F.L. Bunnell of the University of British Columbia and the personnel of the British Columbia Ministries of Environment and Forests for collecting the lichens. The study was funded by the U.S. Forest Service and Washington State University.

Manuscript accepted 14 July 1987.
}

Twelve captive deer were given access to small amounts of lichens and the normal alfalfa-grain pelleted diet for 2 weeks. Although some animals refused lichens, those that began eating lichens were separated into individual pens where lichen intake could be measured. The pellets offered were gradually reduced and lichen increased to determine maximum lichen intake while maintaining healthy deer. This level of lichen intake ( $25 \%$ of the diet) was continued as the alfalfa-grain pellets were switched to alfalfa pellets. Five digestion trials of each of the 2 diets ( $100 \%$ alfalfa pellets and $75 \%$ alfalfa pellets $-25 \%$ lichens) were completed. Intakes of the 2 diets were approximately the same $(1,200 \mathrm{~g} / \mathrm{day})$. Digestion trials were 7-day total collection trials with the animals confined to crates. Because of the time necessary to habituate the deer to lichens as well as establish a constant intake, the deer had been consuming lichens for approximately 1 month before collections began. Pretrials for the alfalfa pellet digestion trials were 10 days with these trials immediately following the mixed diet trial.

Subsamples of the lichen and alfalfa pellets were taken daily and pooled for later analyses. Dry matter content of the feed during each trial was determined on samples dried at $100^{\circ} \mathrm{C}$. Fresh fecal samples that were not contaminated with urine or hair were collected by rectally stimulating each animal to defecate twice daily during the trial. All other feces were dried at the end of the trial at $100^{\circ} \mathrm{C}$, weighed, and discarded. The fresh feces were frozen $\left(-20^{\circ}\right.$ C) until the end of the trial when a subsample was dried $\left(40^{\circ} \mathrm{C}\right)$ and ground for all chemical analyses. Detergent analyses of the feed and feces were done sequentially and without sodium sulfite and decahydronapthalene (Mould and Robbins 1981). Crude protein $(\mathrm{N} \times 6.25)$ was determined using macro-kjeldahl procedures.

\section{Results}

The arboreal lichen was very low in crude protein and fiber (Table 1, Rochelle 1980). Virtually all of the lichen dry matter was soluble in neutral and acid detergent. The very small residual ADF was dark brown and suggestive of bark or other tree residue as the lichen is pale green. Lichens differ chemically from vascular plants in not having cellulose and lignin (Hale 1974), although allelo-

\section{Table 1. Composition (100\% dry matter basis) and digestibility (\%) of alfalia pellets, an arboeal lichen (Alectoria samentosa), and a mixture of the 2. Digestibilities are means \pm 1 S.D.}

\begin{tabular}{|c|c|c|c|}
\hline Composition & Alfalfa pellets & Lichen & \\
\hline $\begin{array}{l}\text { Crude protein } \\
\text { NDF } \\
\text { ADF } \\
\text { Lignin } \\
\text { Cutin }\end{array}$ & $\begin{array}{r}19.8 \\
48.7 \\
35.0 \\
9.3 \\
2.1\end{array}$ & $\begin{array}{r}2.0 \\
13.4 \\
0.9 \\
- \\
-\end{array}$ & \\
\hline Digestibility & $\begin{array}{l}\text { Alfalfa } \\
\text { Pellets }\end{array}$ & $\begin{array}{l}75 \% \text { Alfalfa Pellets } \\
25 \% \text { Lichens }\end{array}$ & Lichen \\
\hline $\begin{array}{l}\text { Dry matter } \\
\text { Crude protein } \\
\text { NDF } \\
\text { NDS }\end{array}$ & $\begin{array}{l}56.4 \pm 1.2 \\
69.7 \pm 1.7 \\
47.9 \pm 1.3 \\
64.5 \pm 1.3\end{array}$ & $\begin{array}{l}63.6 \pm 1.81 \\
60.3 \pm 2.6 \\
51.6 \pm 1.7 \\
71.6 \pm 1.7\end{array}$ & $\begin{array}{r}85.2 \pm 3.5^{2} \\
-218.0 \pm 5.1 \\
91.9 \pm 3.2 \\
84.2 \pm 3.2\end{array}$ \\
\hline
\end{tabular}

'All mean digestibilities for the mixed diet are significantly different from the digestibilities of the alfalfa pellets (t-test, $P<0.01$ ).

2 Variance of the lichen digestibilities estimated as the variance of a linear combination (Dunn and Clark 1974). 
chemicals, such as soluble phenolics, could polymerize during detergent extraction to give a lignin artifact.

Dry matter, NDF, and cell soluble (NDS) digestibilites increased while crude protein digestibility decreased when lichens were fed with the alfalfa pellets (Table 1). The reduction in apparent protein digestibility is partially due to lichen's low crude protein content. Metabolic fecal losses can not be balanced with a forage containing $2 \%$ protein (Robbins 1983).

\section{Discussion}

The estimated dry matter, NDF, and NDS digestibilities for the lichen were very high and in general agreement with the earlier in vitro determinations (Rochelle 1980). Several areas of further study are warranted. The crude protein content $(2 \%)$ is below the dietary level suggested as necessary for efficient rumen bacterial digestion of plant cell walls [6 to 8\%, Van Soest (1982)]. Although many deciduous winter browse stems when consumed with lichens in a mixed diet would provide approximately the level of dietary protein recommended by Van Soest (Robbins et al. 1987a), many plant leaves contain tannins that could reduce protein availability in those forages below the recommended level (Robbins et al. 1987a). However, organic matter digestibility of a terrestrial lichen (Cladonia alpestrix) containing $3.1 \%$ crude protein was not improved by the addition of urea (Jacobsen and Skenneberg 1975). Secondly, the allelochemicals in lichens may restrict intake or require dilution by other dietary constituents to reduce their concentration to a level that is neither toxic to the rumen microbes nor to the animal. Thus, the digestibilities reported for the arboreal lichen in this study may be higher than would be observed with natural diets because the alfalfa contained adequate nitrogen and the lichen was a relatively small percent of the mixed diet. Finally, digestive synergism between lichens and other diet constituents should be explored (Rochelle 1980).

\section{Literature Cited}

Dunn, O.J., and V.A. Clark. 1974. Applied statistics: Analysis of variance and regression. John Wiley and Sons, New York.

Hale, M.E., Jr. 1974. The biology of lichens. American Elsevier Pub. Co., New York.

Hantey, T.A., and J.D. McKendrick. 1983. Seasonal changes in chemical composition and nutritive value of native forages in a spruce-hemlock forest, southeastern Alaska. U.S. Forest Serv. Res. Pap. PNW-312. Portland, Ore.

Hodgman, T.P., and R.T. Bowyer. 1985. Winter us of arboreal lichens, Ascomycetes, by white-tailed deer, Odocoileus virginianus, in Maine. Can. Field-Natur. 99:313-316.

Jacobsen, D., and S. Skjenneberg. 1975. Some results from feeding experiments with reindeer. Proc. Int. Reindeer and Caribou Symp. 1:95-107.

Mould, E.D., and C.T. Robbins. 1981. Evaluation of detergent analysis in estimating the nutritional value of browse. J. Wildl. Manage. 45:937-947.

Person, S.J., R.E. Pegau, R.G. White, and J.R. Lulek. 1980. In vitro and nylon-bag digestibilities of reindeer and caribou forages. J. Wildl. Manage. 44:613-622.

Robbins, C.T. 1983. Wildlife feeding and nutrition. Academic Press, New York.

Robbins, C.T., T.A. Hanley, A.E. Hagerman, O. Hjebjord, D.L. Baker, C.C. Schwartz, and W.W. Mautz. 1987a. Role of tannins in defending plants against ruminants: Reduction in protein availability. Ecology 68:98-107.

Robbins, C.T., S. Mole, A.E. Hagerman, and T.A. Hanley. 1987b. Role of tannins in defending plants against ruminants: Reduction in dry matter digestion? Ecology (submitted)

Rochelle, J.A. 1980. Mature forests, litterfall, and patterns of forage quality as factors in the nutrition of black-tailed deer on northern Vancouver Island. Ph.D. Thesis, Univ. of British Columbia, Vancouver, B.C., Canada.

Silver, H., and N.F. Colovos. 1957. Nutritive value of some forage rations of deer. Tech. Circ. 15, New Hampshire Fish and Game Dep., Durham.

Thomas, D.C., and P. Kroezer. 1981. Digestibility of plants in ruminal fluids of barren-ground caribou. Arctic 34:321-324.

Thomas, D.C., P. Kroeger, and D. Hervieux. 1984. In vitro digestibilities of plants utilized by barren-ground caribou. Arctic 37:31-36.

Van Soest, P.J. 1982. Nutritional ecology of the ruminant. $O$ and B Books, Corvallis, Ore.

\section{Deadline Dates for Advertising and Announcements \\ Journal of Range Management \\ March Issue- February 5. 1987 \\ May Issue-April 6, 1987 \\ July Issue-June 8, 1987 \\ September Issue-August 10, 1987 \\ November Issue-October 8, 1987 \\ Rangelands \\ April Issue - March 10, 1987 \\ June Issue- May 7, 1987 \\ August Issue-July 8, 1987 \\ October Issue--September 8, 1987 \\ December Issue - November 4, 1987}

Copy must arrive by the above dates. For l-time advertising that requires cover space or an entire page, an insertion order must arrive two (2) weeks prior to the above dates. 